\title{
RARE AND ENDANGERED NATIVE PLANT SPECIES IN SASKATCHEWAN SOUTH OF LAT. 55
}

JOHN H. HUDSON, Fraser Herbarium, University of Saskatchewan, Saskatoon S7N OWO

My first intention in writing this memorandum was to catalogue the native species whose survival is threatened in the inhabited parts of Saskatchewan. Then other members of the committee that I was working with in Saskatoon suggested the inclusion of rare species known only from a few locations which might be under no present threat of extermination, but could be wiped out easily by "development."

All opinions about rarity of species, their tendency to decrease or otherwise, and the causes thereof, are my own, formed in 25 years of collecting in the southern and central parts of Saskatchewan. Most rare Boreal Forest species have been mentioned only to the extent that they either straggle down into the northern fringes of the inhabited area, or as 1 have encountered them in my own collecting around Flin Flon. No pretense is made of treating all of the rare boreal species, especially the rare high-northern species, north of about lat. $55^{\circ} \mathrm{N}$, as my field experience extends no further north; someone better informed than I will have to write this.

All statements about range apply only to Saskatchewan, unless otherwise stated. Most of our rarities of southeastern Saskatchewan range east to Ontario or even further, by way of southern Manitoba and the American upper mid-west.

Species known only from the Cypress Hills, hence known in Saskatchewan from a limited area, are mentioned with the sole comment "Cypress Hills", even if common there. Unless otherwise stated, all Cypress Hills plants may be expected to have wide ranges further west (and usually disjunctly) in the Cordillera of North America.
No mention has been made of in troduced species, some of which, course, are rare but whose survival of less interest because they do nc represent elements of our nativ flora.

The statements about range an habitat are mainly my own, but muc help has been derived from Breitung Catalogue. ${ }^{2}$ Locality citations not Breitung are largely my own, or hav been taken from the shelves of th Fraser Herbarium.

The principal present threats plant survival are:

1) Agriculture. When crop prices a depressed farmers must enlarg their cultivated acreage to sprea their overhead over a greater are and when prices are high they ar tempted to add margin. agricultural land to their cultivate acreage in the hope of makin greater profits.

2) Overgrazing. This is a sin of th small operator or mixed farmer e pecially. Actually high farm pric are the best antidote to this.

3) Governmental Action. In this is it cluded schemes to put dams wooded valleys with habitat co taining rare species (see commen on Astragalus purshii), destructio of aspen parkland to make con munity pastures of cultivate grasses, replacement of prairie $b$ cultivated grasses such as Creste Wheat grass, and drainag schemes. All one can do here keep the public informed abo such schemes; one can at lea count on the societies of hunte for help against drainage scheme

4) Weed Spread. The introduced pe species Perennial Sowthistl Awnless Brome, Couch Gras Canada Thistle, Dandelion, and (i dry ground) Crested Wheat-gras 
have a particularly noxious influence on the remaining stands of native vegetation in that they spread into these stands and take over. This would be because their natural enemies in Europe haven't come over with them to control their numbers. Seeking out these natural enemies and introducing them (after checking that these enemies don't attack anything native) would seem to be biologically and politically possible, at least for Sow Thistle, Canada Thistle, and Dandelion. The pest grasses mostly have close native relatives and also it would evoke political opposition to destroy them even if possible.

Picking. Not a major threat except to Western Red Lily, the Yellow Lady's-Slippers, Venus' Slipper, Crocus Anemone, and possibly to Cliff-brake.

\section{PECIES LIST}

\section{PHIOGLOSSACEAE - GRAPE FERN AMILY}

otrychium lunaria. Moon-fern. Very rare ow but always was rare or sporadic. leavy grazing on aspen woods on andhills endangers this one.

otrychium multifidum. Leathery-leaved rape-fern. Moist prairie. Rare.

\section{OLYPODIACEAE-FERN FAMILY}

ystopteris montana. Mountain Bladderrn. Porcupine Mountain only.

llaea glabella. Cliff-brake. A rock fern owing in cracks of limestone or dolomite iffs, known from Amisk Lake, Athabasca ke, Limestone Lake, Roche Percee, Big uddy Valley. A station could be cleaned it even by botanical collectors if there ere many of them.

oodsia glabella. Smooth Woodsia. A rare rn of limestone cliffs known from Amisk d Athabasca Lakes.

oodsia oregana. Oregon Woodsia. Not common in basic rocks in the Precamian, as at Denare Beach and Athabasca ke; unlike most other northern rock rns, occurs southward at a few places, as press Hills and Big Muddy Valley. Very e southward.

LAGINELLACEAE LAGINELLA FAMILY
Selaginella selaginoides. Prickly Selaginella. A rare species of marl bogs, mostly in the southerly parts of the Boreal Forest.

\section{PINACEAE - PINE FAMILY}

Pinus contorta latifolia. Lodgepole Pine. Cypress Hills, the dominant evergreen.

\section{NAJADACEAE - PONDWEED FAMILY}

Najas flexilis. Water-nymph. Big Sandy Lake, Pike Lake.

Potamogeton foliosus. Leafy Pondweed. Saskatoon, Candle Lake, Caron, Mortlach. There is a large number of pondweeds (Potamogeton) for which few reports exist. Difficulties of identification are mainly responsible for the fewness of the reports. Such difficulties are especially severe for the narrow-leaved pondweeds such as this one. There are, too, at least five species of rarely reported pondweeds confined in Saskatchewan to the Boreal Forest region.

\section{JUNCAGINACEAE - ARROW-GRASS FAMILY}

Scheuchzeria palustris. Scheuchzeria. Bogs (sphagnous?) P.A. National Park, Candle Lake. This must indeed be scarce, as I have never seen this in the field.

\section{LILAEACEAE - FLOWERING QUILLWORT FAMILY}

Lilaea scillioides. Flowering Quillwort. Rare - grows around sloughs and in dry creek beds. Trossachs, Spring Valley, Cypress Hill (Fairwell Creek).

\section{HYDROCHARITACEAE - WATER - WEED FAMILY}

Elodea canadensis. Canadian Water-weed. An eastern species found in slow rivers; Souris River at Carnduff; Cumberland House area; Sturgeonweir R. below Amisk Lake.

Elodea nuttallii. Western Water-weed. A western species found in intermittent sloughs; Smiley, Glen Bain, Frontier.

\section{GRAMINAE - GRASS FAMILY}

Alopecurus glaucus. Western Foxtail. Cypress Hills.

Andropogon gerardi. Big Blue-stem. A species of tall-grass prairie in S.E. of province. Now confined there to upper part of valley cutbanks, and easily grazed out.

Aristida longiseta. Red Three-Awn. It has been collected at Val Marie, but I have never seen it in Saskatchewan. 
Bouteloua curtipendula. Side-Oats Grama. Same comments as Andropogon gerardi. Does not go as far north-west.

Calamagrostis rubescens. Pine Grass. Cypress Hills.

Elymus cinereus. Giant Wild Rye. Reported in Breitung's Catalogue from Cypress Hills, Vanguard, and Indian Head. ${ }^{2}$ I have never seen this but once, in a moist draw at Old-Man-on-his-Back plateau.

Elymus glaucus. Smooth Wild Rye. Cypress Hills.

Eragrostis hypnoides. Moss-like Lovegrass. Muddy river bayous, along Souris R. south of Carnduff only.

Festuca idahoensis. Bluebunch Fescue. Cypress Hills.

Glyceria canadensis. Rattlesnake Grass. One disjunct station at Denare Beach.

Hordeum brachyantherum. Meadow Barley. Cypress Hills.

Milium effusum. Millet-grass. Porcupine Mountain.

Munroa squarrosa. False Buffalo-grass. Saskatchewan Landing (perhaps exterminated by Diefenbaker Lake), Hatton.

Oryzopsis canadensis. Canadian Ricegrass. Edges of aspen bluffs, north margin Park Belt, particularly vulnerable to squeeze-out by bromegrass.

Panicum depauperatum. Starved Panicgrass. Moosomin only. I have not seen this one.

Panicum subvillosum. Hairy Panic-grass. Creighton, Amisk Lake, Lake Athabasca; sandy or rocky pine woods in Boreal Forest.

Panicum virgatum. Switch Grass. Extreme southeast corner of the province; same comments as Andropogon gerardi.

Panicum wilcoxianum. Wilcox's Panicgrass. Sand barrens, east half of Park Belt; Welby, Prince Albert, MacDowell, Goodwater.

Panicum xanthophysum. Yellow-green Panic-grass. Rock outcrops. Denare Beach, Creighton.

Phleum alpinum. Mountain Timothy. Cypress Hills.

Sitanion hystrix. Squirrel Tail. Reports scanty; Val Marie, Hatton, Beechy. Not really rare on bare clays and eroded bedrock outcrops in southwest.

Sporobolus heterolepis. Prairie Dropseed. Another grass of tall-grass prairie in the southeast. Same comments as for An- dropogon gerardi.

Sporobolus neglectus. Small Dropseed. Disturbed places, Estevan.

Stipa richardsonii. Richardson's Speargrass. Cypress Hills mainly, a very few outlying stations further northeast.

Trisetum spicatum. Spike Trisetum. An arctic-alpine species found in the Cypress Hills and reappearing in the N.E. corner of the province (Hasbala Lake).

Trisetum wolfii. Wolf's Trisetum. Cypress Hills.

\section{CYPERACEAE-SEDGE FAMILY}

Carex alopecoidea. Foxtail Sedge. Woods; McKague, Mortlach, Estevan, Craven, Katepwa, Wood Mountain Park.

Carex arcta. Bear Sedge. Amisk Lake, Candle Lake.

Carex granularis. Granular Sedge. Spy Hill, Welby, Pipestone Valley, Good Spirit Lake. Carex gravida. Heavy-fruited Sedge Roche Percee, Oxbow, Willowbunch, Shand.

Carex hoodii. Hood's Sedge. Cypress Hills. Carex laxiflora. Loose-flowered Sedge. Porcupine Mountain.

Carex meadii and Carex tetanica. May be the same species. This was rare on moist prairie in the lower $\mathrm{Qu}$ 'Appelle valley area in old John Macoun's time. I cannot find it now. Probably it has been exterminated by tillage and by the proliferation of Bromus inermis (brome grass) on untilled moist prairie.

Carex pedunculata. Long-stalked Sedge. Cumberland House, Hudson Bay Junction, Armit.

Carex petasata. Cespitose Sedge. Cypress Hills.

Carex raynoldsii. Raynolds' Sedge. Cypress Hills.

Cladium mariscoides. Twig Rush. Dahlton only. I have never seen this; it must be exceedingly rare. A bog species.

Cyperus strigosus. Straw-coloured Cyperus. A report from Watrous exists; 1 have never seen this one either.

Rhynchospora alba. White Beaked-rush. Bare in Boreal Forest bogs; reported by Breitung from Dahlton, Prince Albert and Nipawin, but there are no specimens in the Fraser Herbarium from Saskatchewan. I have it from Garthland P.O.

Rhynchospora capillacea. Hair-like Beaked-rush. Rare in southern Boreal Forest bogs, often not the same bogs as 


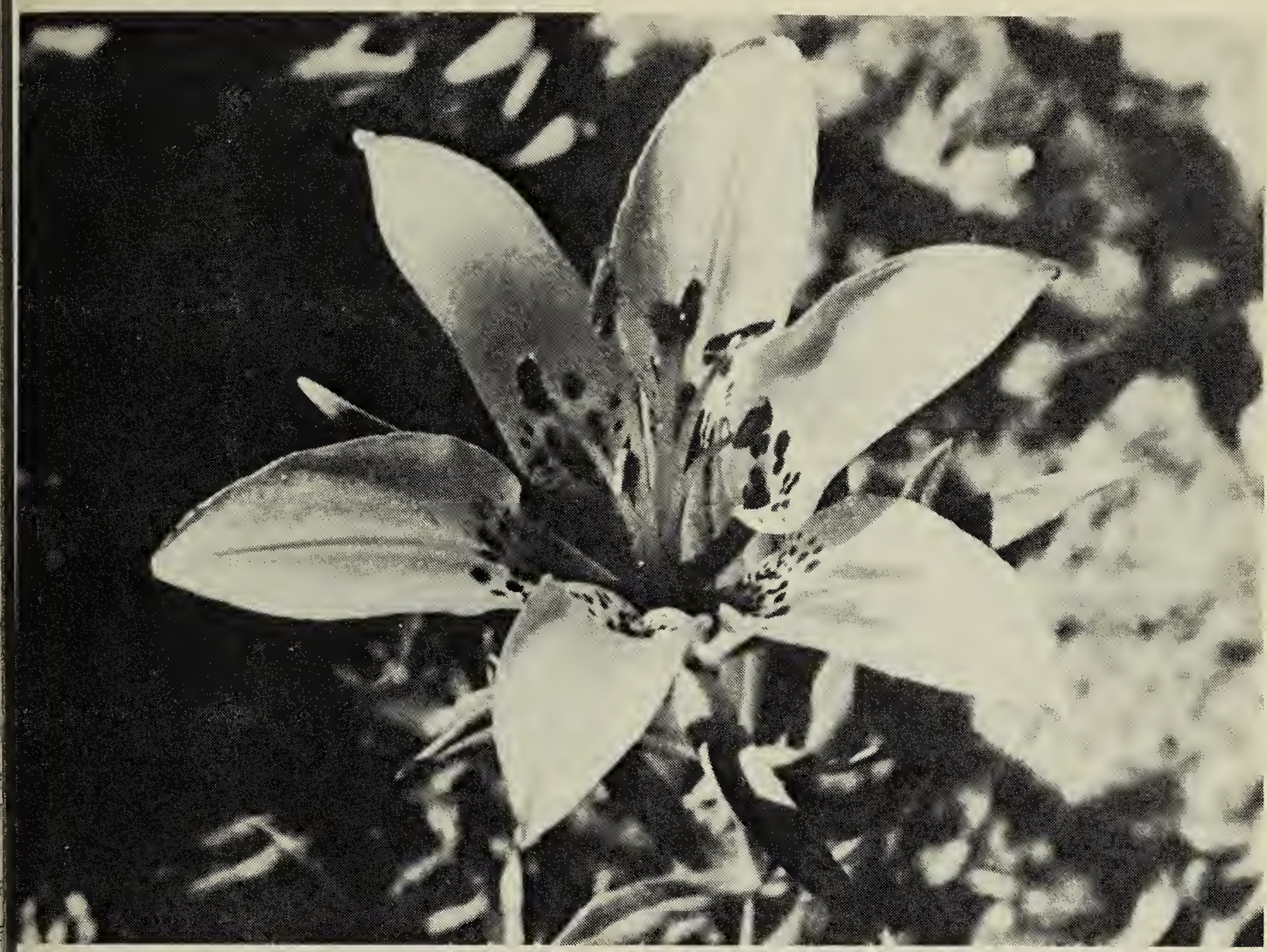

Western Red Lily

R. E. Gehlert

Rh. alba. Nipawin, Wallwort, Mennon, Garthland, P.O.

fcirpus atrovirens. Dark-green Bulrush, Estevan area only.

cirpus clintonii. Clinton's Rush. Rare. Meadow Lake only.

cirpus fluviatilis. River Bulrush. Scarce on marshy shores. Pike Lake (but I haven't een it), Indian Head, Cumberland House, Keg Camp (Churchill R.).

cirpus pumilus. Dwarf Bulrush. Known rom 3 groundwater bogs within 40 miles f Saskatoon. Status OK at present but can e exterminated by drainage.

cirpus rufus. Red Club-rush. As for bove, known from 3 or 4 subsaline roundwater bogs in the Saskatoon area.

\section{UNCACEAE - RUSH FAMILY}

uncus ensifolius. Iris-leaved Rush. Fypress Hills, widespread.

uncus nevadensis. Nevada Rush. Cypress Hills; east block only, so far as known.

uncus stygius. American Bog Rush. Farthland P.O. (Macdowell area); Lake thabasca.
Juncus tracyi. Tracy's Rush. Cypress Hills.

\section{LILIACEAE-LILY FAMILY}

Allium cernuum. Nodding Onion. Confined in Sask. in my experience to the Cypress Hills; reports from elsewhere are almost certainly in error.

Allium stellatum. Pink-flowered Onion. Park Belt. Much reduced by grazing and tillage.

Lilium philadelphicum var. andinum. Western Red Lily. O.K. in Palaeozoic and Precambrian areas of province. Very much reduced in settled area, mostly by overgrazing of the moist calcareo-saline groundwater areas in which it grows best. Picking has had some adverse effect too, near cities, especially since, although perennial, it flowers only once before dying. Its scattered occurrences in aspen woodland have been much reduced by grazing and by influx of drift soil into bluffs which provides an entry for Bromus inermis. Lacking in southwest, but never did occur in Cypress Hills or west of Valjean on the main line.

Polygonatum canaliculatum. Common Solomon's-Seal. Rare, Estevan area. 
Smilacina racemosa. Clasping-leaved Solomon's-Seal. Cypress Hills.

Streptopus amplexifolius. Clasping-leaved Twisted-Stalk. Rare in rich moist aspen woods, Boreal Forest-Aspen Parkland intergrade. Cypress Hills, Meadow Lake, Pasquia Hills, Porcupine Mountain.

Trillium cernuum. Nodding Trillium. Found rarely in moist woods in eastcentral Saskatchewan. Occurrences at Runnymede and Veregin and somewhat affected by grazing. Hudson Bay Junction area more or less OK.

\section{AMARYLLIDACEAE-AMARYLLIS FAMILY}

Hypoxis hirsuta. Hairy Star Grass. In grassy meadows subject to some groundwater influence, Yorkton area. Probably reduced by the infiltration of such meadows by Sonchus arvensis and Cirsium arvense. Rare and at edge of range to begin with.

\section{ORCHIDACEAE-ORCHID FAMILY}

Calypso bulbosa. Venus' Slipper. Rare in pine woods, Cypress Hills, Precambrian of Amisk Lake, and a few scattered stations along the southern edge of the Boreal Forest. A slow reproducer and easily picked out.

Corallorhiza striata. Striped Coral-root. Reported from several locations in the east half of the Park Belt, but I have not seen it outside the Cypress Hills.

Cypripedium arietinum. Ram's Head Lady's-Slipper. Very rare. Prince Albert, Hudson Bay Junction.

Cypripedium calceolus var parviflorum. Small Yellow Lady's Slipper. Growing in wooded bogs and groundwater seeps in the Park Belt, the populations of this Lady's Slipper are not too severely reduced because they are hard to find.

Cypripedium calceolus var pubescens. Large Yellow Lady's Slipper. This largeflowered form grew on moist prairie in the Park Belt in the eastern half of Saskatchewan. Very much reduced, due mainly to tillage. The plants are rhizomatic, so picking is not quite such a menace as for bunched or bulb-bearing species.

Cypripedium passerinum. Sparrow's-egg Lady's Slipper (often, White Lady's Slipper). Rare along springs in coniferous woods.

Goodyera oblongifolia. Menzies' Rattlesnake Plantain, Cypress Hills.

Habenaria dilatata. White Bog Orchid. OK

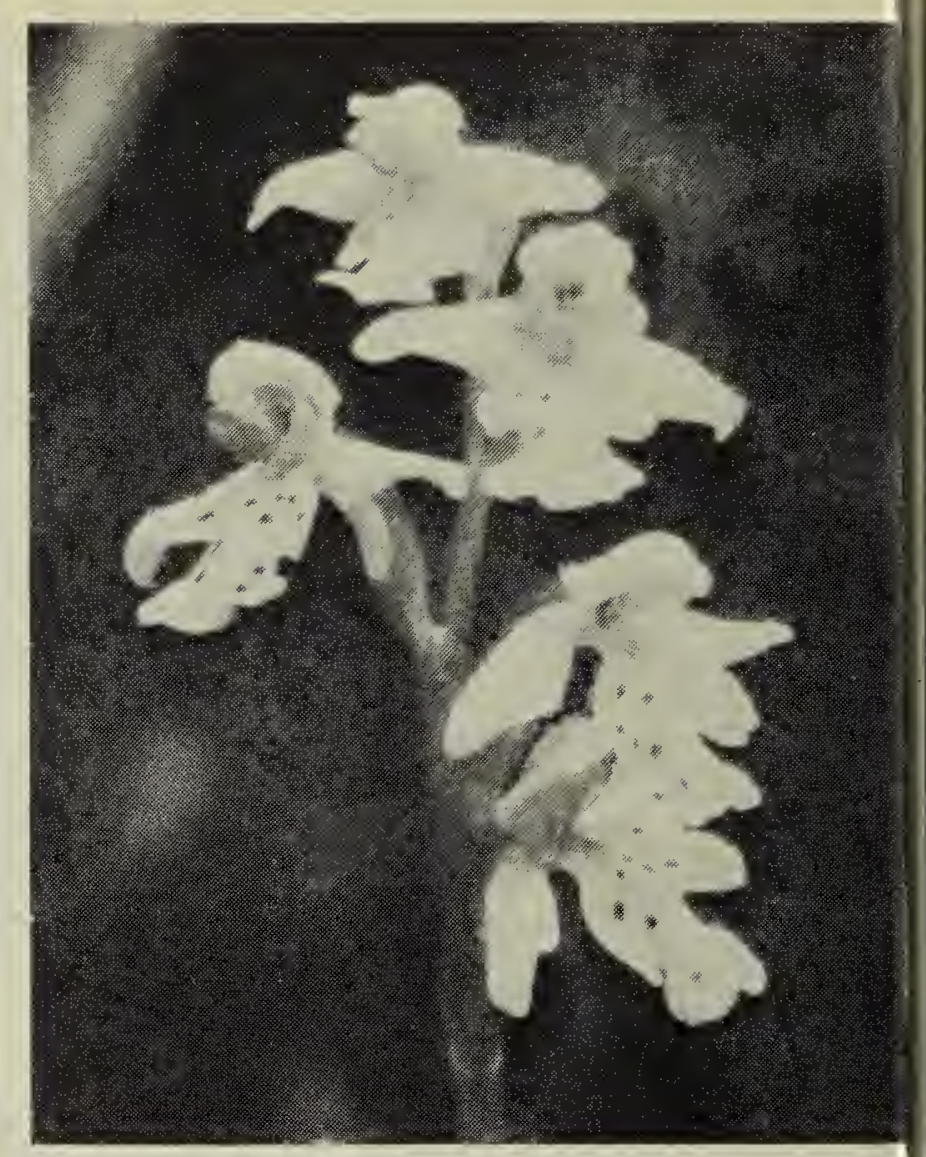

Large Round-leaved Orchid Bob Godwin

as yet in calcareous groundwater-fed bogs in Park Belt, but fate bound up with that of the bogs. Uncommon.

Habenaria orbiculata. Large Round-leaved Orchid. Rare in southern part of Boreal Forest area.

Habenaria viridis var bracteata. Longbracted Orchid. Rare around edges of thickets, wetter parts of Park Belt. Almost always occurs by ones or twos, not by colonies.

Liparis loeselii. Bog Tway-blade. Confined to a few very wet groundwater-fed bogs in east half of Park Belt. Very rare now but always was so. Fate bound up with that of the bogs.

Listera borealis. Northern Tway-blade. Very rare in spruce forests at springy places.

Listera cordata. Heart-leaved Tway-blade In cool spruce woods, reported infrequently, but more because it's hard to see rather than because of great rarity.

Malaxis monophyllos var brachypoda. Adder's Mouth. In coniferous woods; rare and hard to see. MacDowall, Waskesiu.

Malaxis paludosa. Swamp Adder's Mouth. Even rarer and harder to see than the preceding; known only from Garthland P.O. area.

Spiranthes gracilis. Slender Ladies'-Tresses. Rare in sandy pine woods, west half of 
as the Meadow Lake and Loon Lake areas; I have never seen this.

Ranunculus inamoenus. Cypress Hills.

Thalictrum occidentale. Western Meadow Rue. Cypress Hills.

\section{CRUCIFERAE-MUSTARD FAMILY}

Halimolobos virgata. Only few reports: Cypress Hills, Wood Mountain, Birsay. Seems rare but may just be overlooked because of its extreme resemblance to several species of Rock Cross (Arabis). I myself never did recognize it until I memorized the drawing in Flora Pac. N.W., and now I'm fairly sure that I have seen it in the past. ${ }^{3}$

Hutchinsia procumbens. Very seldom collected - Parkbeg, Ingebright Lakes, Indi Lake. A tiny mustard found in earliest spring on the beaches of sodium sulfate lakes.

\section{DROSERACEAE-SUNDEW FAMILY}

Drosera anglica. Oblong-leaved Sundew. Very rare, sopping wet bogs in southern part of Boreal Forest; Prince Albert, McKague, Garthland P.O.

Drosera linearis. Slender-leaved Sundew. Same comments as preceding.

\section{SARRACENIACEAE-PITCHER PLANT FAMILY}

Sarracenia purpurea. Pitcher Plant. Requires large calcareous bogs; very showy in flower; shallowly rooted and subject to picking. Not rare as yet.

\section{CRASSULACEAE-STONECROP FAMILY}

Sedum lanceolatum. Stonecrop. Cypress Hills.

\section{SAXIFRAGACEAE-SAXIFRAGE FAMILY}

Lithophragma bulbifera. Star Flower. Grows along draws on the lower south slopes of the Cypress Hills. Vulnerable to grazing.

Parnassia glauca. American Grass of Parnassus. Marl bogs and groundwater seeps in a limited area of east-central Saskatchewan from Yorkton north to Nipawin. Same comments as for Hypoxis hirsuta.

Saxifraga rhomboidea. Rhomboid-leaved Saxifrage. Cypress Hills.

\section{ROSACEAE-ROSE FAMILY}

Potentilla diversifolia. Varying-leaved Cinquefoil. Cypress Hills.

Prunus americana. Wild Plum. A large shrub or small tree. Souris R. valley fron Estevan downstream. Deforestatio measures or dam-building schemes coul clean this one out. Not presently critical

Prunus pumila. Sand Cherry. Rare on ope sand plains in east-central Sask.; Welby Hudson Bay Junction. Vulnerable to com munity pasture "improvement" schemes

Sorbus americana (incl. S. scopulina of th Cypress Hills) Mountain Ash, Rowan. small tree or large shrub widely but dis continuously distributed in Boreal Fores areas of high moisture efficiency but goo drainage; Cypress Hills, Porcupine Moun tain, Amisk Lake, Little Bear Lake on Han son Lake Road, Lake Athabasca.

Spiraea lucida. Shining-leaved Meadow sweet. Cypress Hills.

\section{LEGUMINOSAE - PEA FAMILY}

Astragalus crassicarpus. Ground Plum Moist prairie. Palatable to grazing. Much reduced by tillage and overgrazing.

Astragalus kentrophyta. Prickly Mil Vetch. Confined in Saskatchewan to a fev gravel barrens in the Great Sand Hills area Webb, Bitter Lake.

Astragalus purshii. Pursh's Milk Vetch Known from very dry prairie, South Saskatchewan River valley south of Kyle and south of Old-Man-on-his-Bacl plateau. Former locality has likely been ex tinguished by the South Saskatchewar dam.

Astragalus racemosus. Racemose Mil Vetch. A large selenium-collecting mill vetch found in Canada only on Bearpav shale outcrops in south-centra Saskatchewan; Moose Jaw, Buffalo Poun Lake, Dirt Hills, Blackfoot Ridge badland at Truax.

Astragalus vexilliflexus. Few-flowered Mil Vetch. Cypress Hills and the Driftless are in the Rockglen district.

Lupinus pusillus. Small Lupine. Rar species of loose sand, southwes Saskatchewan. Needs disturbance for sur vival. Can be extinguished if blowouts ar permitted to revegetate with grass.

Oxytropis besseyi. Bessey's Locoweed Known in Canada only from silt buttes o the Ravenscrag formation in the driftles areas at Rockglen-Killdeer and the lowe Frenchman river valley. No present threat

Oxytropis lambertii. Lambert's Loco-weed A loco-weed with long spikes of show magenta flowers found only in the ex treme south-east; Estevan, Goodwater.

Petalostemon villosum. Hairy Prairi 
Clover. Known in Saskatchewan only from the Caron-Mortlach area on loose sand in blowouts; threatened by natural regrassing of blowouts there.

\section{GERANIACEAE - GERANIUM FAMILY}

Geranium richardsonii. White Wild Geranium. Cypress Hills.

Geranium viscosissimum. Sticky Purple Geranium. Common, Wood Mountain hlateau; West Block only, Cypress Hills. There are reports and specimens from the Touchwood Hills area, which must be an solated pocket of the range.

\section{POLYGALACEAE - MILKWORT FAMILY}

Oolygala alba. White Milkwort. Found in Canada only on dry eroded slopes in the Estevan, Souris River, and Big Muddy Valley areas; abundant enough there.

olygala paucifolia. Pink Fringed Milkwort. Discontinuously distributed in he southern part of the Boreal Forest, avouring high-lime areas. I have seen it at MacDowall, Hudson Bay Junction, and misk Lake, and there are reports or pecimens to hand from McKague, hellbrook, and Candle Lake.

olygala senega. Seneca Snakeroot. robably reduced as much by the collecon of seneca roots for medicine as by griculture. Even now not hard to find if ne knows where to look for it.

olygala verticillata. Whorled Milkwort. ne location on valley bottom of a side oulee of Souris R., 4 miles west of Estevan. nnual and seems to behave like a desert. phemeral in that the population is not ways visible every year.

\section{NACARDIACEAE - SUMAC FAMILY}

hus glabra. Smooth Sumac. One colony nown, on shore of Little Birch Lake near in Flon.

\section{ELASTRACEAE - \\ TAFF TREE FAMILY}

elastrus scandens. Climbing Bittersweet. nown from one tract of brush on river luffs of Souris valley south of Estevan. his is right at the edge of the range, so it puld easily be wiped out by climatic garies even without human inrrference.

\section{UTTIFERAE -}

\section{T. JOHN'S WORT FAMILY}

ypericum virginianum var fraseri. rginia St. John's-wort. Sedge swamps; misk Lake, Saskatchewan River delta.

OLACEAE - VIOLET FAMILY
Viola pedatifida. Crowfoot Violet. Moist prairie in prairie and parkland regions. Much reduced by tillage and overgrazing; now hard to find.

Viola pubescens var leiocarpa. Yellow Wood Violet. Wet woods, Armit.

Viola selkirkii. Selkirk's Blue Violet. Rare, wet woods, east end of Boreal Forest; Amisk Lake, Porcupine Mountain, Saskatchewan River delta. The seldom collected $V$. palustris of wet alder woods and $V$. renifolia of upland white spruce forest (both in the Boreal Forest zone) are not really rare, just inconspicuous; $V$. renifolia furthermore blooms very early.

\section{ONAGRACEAE - EVENING PRIMROSE FAMILY}

Oenothera breviflora. Taraxia. Rare, S.W. Saskatchewan, around alkali lakes and on dry slough bottoms.

\section{HALORAGIDACEAE - WATER MILFOIL FAMILY}

Myriophyllum pinnatum. Pinnate WaterMilfoil. Shallow water on southern prairies; Wordsworth.

\section{UMBELLIFERAE - CARROT FAMILY}

Lomatium dissectum. Mountain Wild Parsnip. West Block Cypresi Hills only. Must be very rare; I have never seen it.

Lomatium cous (L. montanum). Cous. Confined in Canada, so far as is known, to late-snow areas just below plateau level in West Block Cypress Hills of Saskatchewan.

Lomatium orientale. White-flowered Parsley or Cous. Rare along Souris River valley from Estevan downstream on dry benches. No present threat but could be wiped out by "development."

Perideridia gairdneri. Yamp, Squaw-root. Cypress Hills.

Zizia aurea. Golden Alexanders. One report for Saskatchewan, at Strongfield, but the specimen is an aberrant $Z$. aptera (Meadow Parsnip).

\section{PYROLACEAE - WINTERGREEN FAMILY}

Monotropa hypopithys. Pine-sap. A rare saprophyte of the Cypress Hills.

Pterospora andromedea. Pine-drops; Giant Bird's Nest. Rare in lodgepole pine woods in Cypress Hills; could be easily cleaned out by picking, as it is very spectacular, almost weird-looking, and occurs singly.

Pyrola minor. Lesser Wintergreen. Rare, Cypress Hills and Precambrian part of 
Boreal Forest.

\section{PRIMULACEAE - PRIMROSE FMAILY}

Dodecatheon conjugens. CylindricFlowered Shooting Star. Cypress Hills.

Dodecatheon pulchellum. Shooting Star. Meadows in calcareous zone of groundwater outcrops. Can be reduced by overgrazing or by sowthistle spread inio these areas. Showy.

Primula incana. Mealy Primrose. Same comments as for Shooting Star.

Primula mistassinica. Dwarf Canadian Primrose. A few reports from Boreal Forest areas; I cannot say whether or not is is rare.

\section{GENTIANACEAE - GENTIAN FAMILY}

Gentiana affinis. Oblong-leaved Gentian. Same comments as for Shooting Star.

Gentiana andrewsii. Bottle Gentian. Moist prairie, lower Qu'Appelle Valley area. At the edge of its range, subject to wiping out by tillage and sowthistle spread. I have not seen it despite looking. Probably extinct.

\section{ASCEPIADACEAE - MILKWEED FAMILY}

Asclepias verticillata. Whorled Milkweed. A few locations on dry flats in Souris River valley west of Estevan.

\section{POLEMONIACEAE - PHLOX FAMILY}

Linanthus septentrionalis. Northern Linanthus. An inconspicuous early-spring annual of grassy slopes confined in Saskatchewan to the high plains south of the Cypress Hills and to Pinto Butte.

Phlox alyssifolia. Blue Phlox. Wood Mountain - Big Muddy Valley area only.

\section{BORAGINACEAE - BLUE BUR FAMILY}

Lithospermum ruderale. Woolly Gromwell. West Block Cypress Hills only.

Onosmodium molle var occidentale. Western False Gromwell. Around edges of brush and groves, Souris River valley below Estevan. Threatened by bromegrass aggression.

\section{VERBENACEAE - VERVAIN FAMILY}

Verbena hastata. Blue Vervain. Rare on moist banks and shores, southeast corner - Roche Percee; there is an outlying collection from Wadena.

Verbena urticifolia. Nettle-leaved Vervain. One location on the banks of the Antler River south of Gainsborough; visibly threatened by the spread of sowthistle.
LABIATAE - MINT FAMILY

Scutellaria lateriflora. Blue Skull-cap. Distribution southeastern; Trossachs, Souris River valley, Armit.

\section{SOLANACEAE - POTATO FAMILY}

Physalis grandiflora. Large White-flowered Ground-Cherry. Very rare; grows by ones and twos on disturbed bare sand in Boreal Forest areas. Civilized man has introduced many weedy annuals quick to take over such disturbed sands.

\section{SCROPHULARIACEAE - SNAPDRAGON FAMILY}

Besseya wyomingensis. Kitten-tails. West Block Cypress Hills.

Castilleja coccinea. Scarlet Paint-brush Reported from a damp meadow near Buchanan about 1920; not collected since I have never seen it. Probably extinct in Saskatchewan, but was here at the northwest edge of the range anyway. Same comments as Bottle Gentian.

Mimulus glabratus. Small Yellow Monkeyflower. A few reports from shady boggy springs in the Qu'Appelle and Pipeston* valleys. It must be very rare; I've never seen it.

Mimulus guttatus. Yellow Monkey-flower Cypress Hills, abundant and widespread.

Mimulus ringens. Blue Monkey-flower Reported by Breitung from the banks o the Red Deer River at Hudson Bay Junc tion. ${ }^{2}$ I could not find it there, but the river was in high water then. An eastern species.

Rhinanthus crista-gallii. Yellow Rattle Cypress Hills mainly (I have not seen i elsewhere); Ile a la Crosse; I question the locality data on the Carnduff sheet in the Fraser Herbarium.

Veronica serpyllifolia var humifusa Northern Thyme-leaved Speedwell Cypress Hills.

\section{LENTIBULARIACEAE - BLADDERWORT FAMILY}

Pinguicula vulgaris. Butterwort. Known from a few calcareous bogs in the Park Bel - Prince Albert, Mennon, Strawberry Lakes, Candle Lake. Its future is bound up with the future of these bogs.

OROBANCHACEAE -

BROOMRAPE FAMILY

Orobanche uniflora. One-flowered Cancer Root. One Cypress Hills record.

CAPRIFOLIACEAE -

HONEYSUCKLE FAMILY 


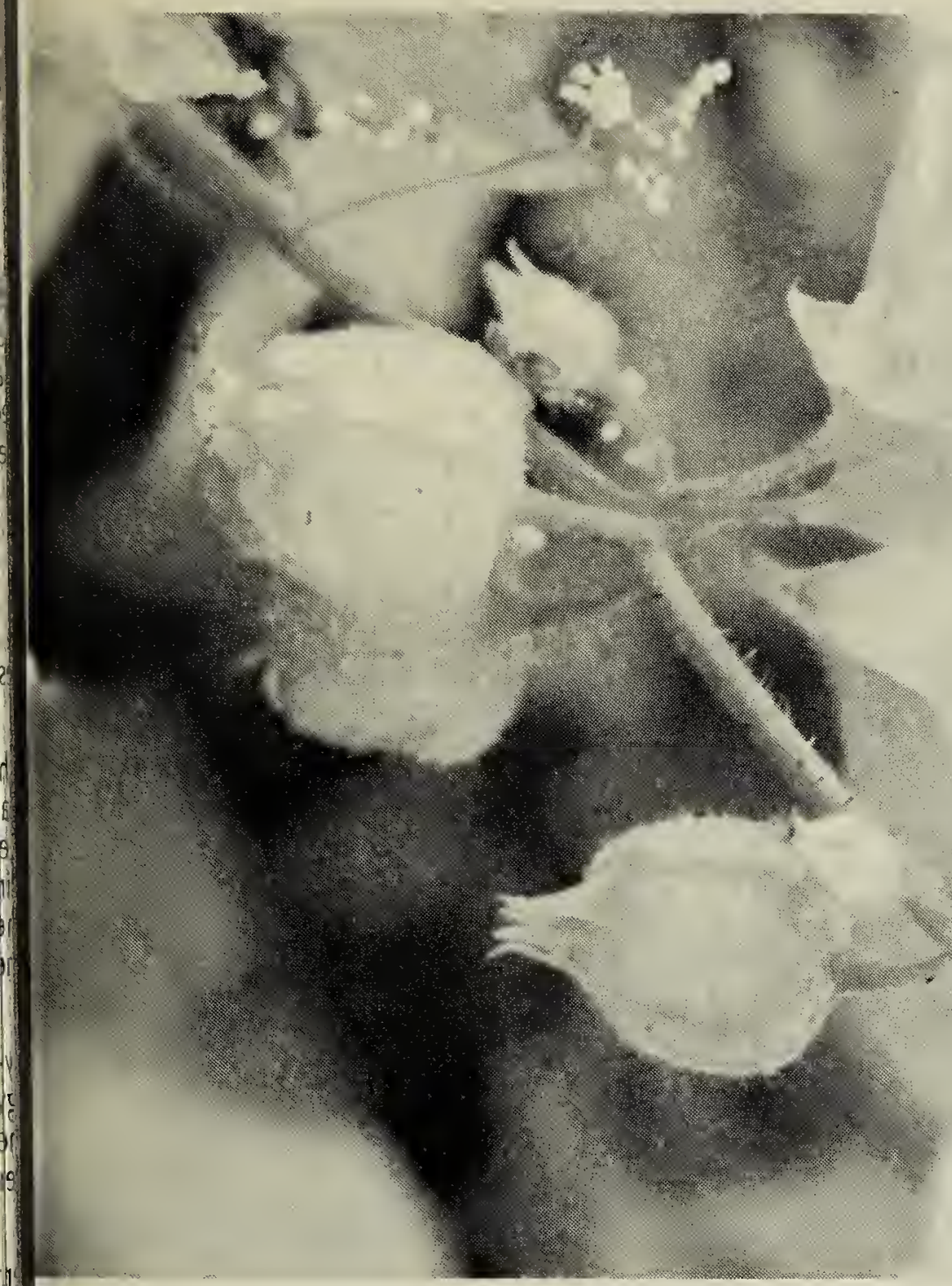

arge White-flowered Ground-Cherry

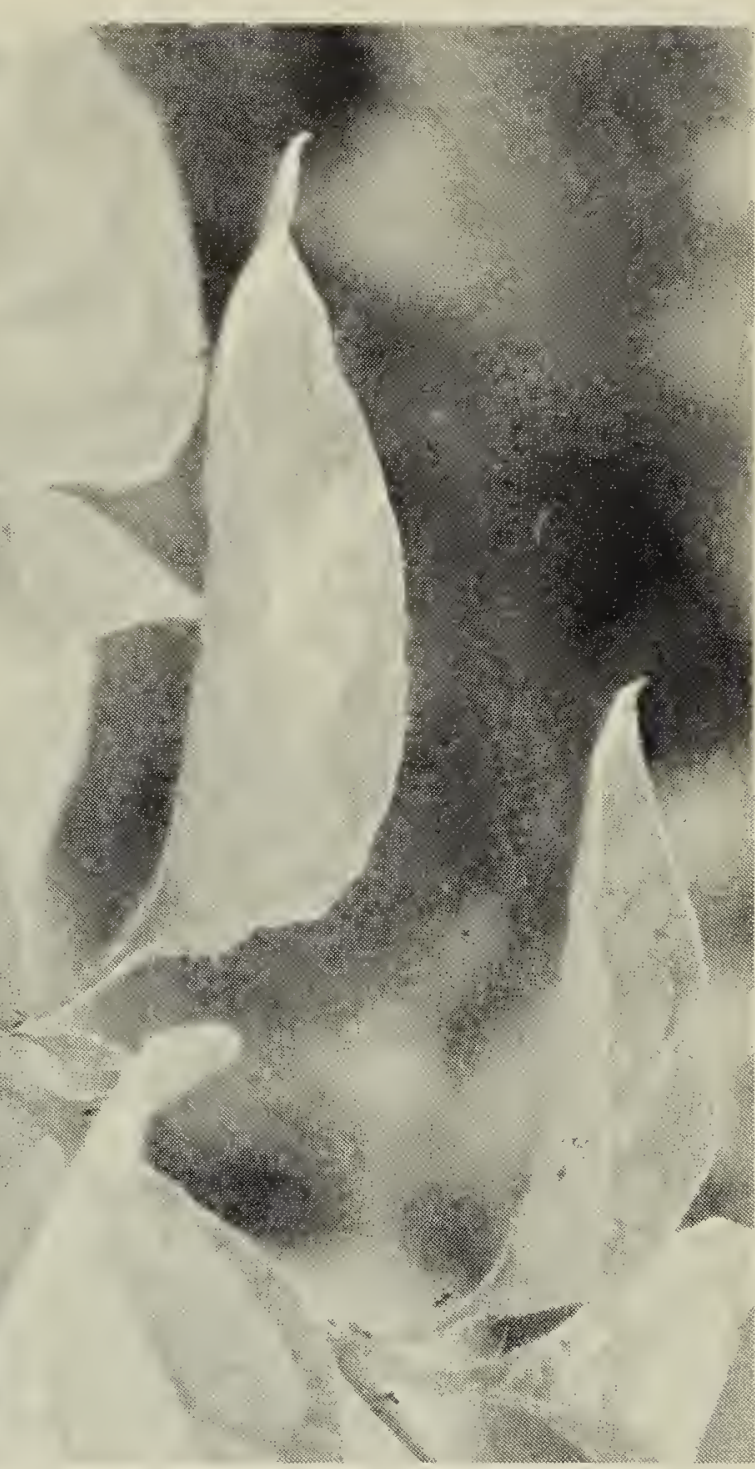

Wayne Harris ambucus pubens. Red-berried Elder. ower Saskatchewan river near umberland House; Armit. A large shrub if wet woods, plainly confined to the first rairie level or Lake Agassiz bottom in askatchewan.

iburnum lentago. Nanny-berry. A shrub extreme S.E. corner of the province. ery rare - I have not seen it. Same comhents as Prunus americana.

\section{DOXACEAE - MOSCHATEL FAMILY}

doxa moschatellina. Moschatel. Under strich Fern clumps in wet spots along ver banks in Boreal Forest; records scan, but plant very hard to spot. Height of ind 17 miles south of Meadow Lake; Canle Lake; Pasquia Hills (Boivin).'

\section{ORANTHACEAE - MISTLETOE AMILY}

rceuthobium pusillum. Spruce Mistletoe. udson Bay Junction only. By the descripons given, this would appear to be very luch more difficult to spot than the idespread Pine Mistletoe, $A$. mericanum.

\section{LOBELIACEAE - LOBELIA FAMILY}

Downingia laeta. Downingia. A small mud annual with pink flowers collected in the 1890's by John Macoun at Crane Lake and Skull Creek, and still present along Skull Creek in the late 1950 's. I have never seen it elsewhere.

\section{COMPOSITAE - COMPOSITE FAMILY; TUBULIFLORAE - THISTLE SUB' FAMILY}

Anaphalis margaritacea. Pearly Everlasting. Cypress Hills; Cutknife.

Antennaria dimorpha. Stemless Everlasting. A rare species of very dry prairie south of the Cypress Hills. Divide, Climax.

Antennaria anaphaloides. Anaphalis-like Pussy-toes. Cypress Hills.

Antennaria corymbosa. Corymbose Pussytoes. Cypress Hills. A doubtful segregate out of the $A$. rosea - A. microphylla (smallleaved Pussy-toes) complex.

Antennaria umbrinella. Brown-bracted Pussy-toes. Cypress Hills. 
Arnica cordifolia. Heart-leaved Arnica. Cypress Hills, with a few outlying localities elsewhere - Waskesiu Lake, Pasquia Hills (Boivin, part III).

Arnica fulgens. Shining Arnica. Moist prairie, grassland zone. Much reduced by cultivation, overgrazing, and drifting of blow dirt onto road allowances.

Aster eatonii. Eaton's Aster. Cypress Hills.

Aster umbellatus var pubens. Flat-topped Aster. Spy Hill area only, growing among brush. Seemed OK for the time being when I collected it.

Bahia oppositifolia. Bahia. Rare in very arid places, extreme south; probably native. Field weed at Pambrun; in alkaline valleys at Divide (on the south side of the OldMan-on-his-Back); and I have seen it in the Big Muddy.

Bidens beckii. Water Marigold. Quiet waters, Cumberland House area.

Boltonia asteroides. Aster-like Boltonia. Wet clayey disturbed places, such as tilled sloughs and road ditches, south-central Saskatchewan, mostly on the Regina Plain; Torquay, Weyburn, Milestone, Baildon. Abundant but seldom reported because of its extreme likeness to Aster hesperius, Western Aster, of similar habitats.

Cirsium drummondii. Stemless Thistle. Moist prairie at edges of brush in Park Belt. Much reduced by cultivation and spread of bromegrass. The only locations where I have seen it are MacDowall Forest Reserve and the Runnymede-Togo area.

Cirsium muticum. Swamp Thistle. Rare in swamps and alder thickets, east half of the intergrade between Park Belt and Boreal Forest. There are several citations in Breitung but the only place that I have seen it is Armit. ${ }^{2}$ It is subject to aggression by sowthistle.

Echinacea angustifolia. Purple Coneflower. Another Souris River specialty; grows on dry slopes along the Souris River at least as high up as Goodwater. I have seen it on slopes near Big Beaver.

Erigeron radicatus. Dwarf Fleabane. Dry eroded slopes and badlands, Wood Mountain area and Cypress Hills. Reports from elsewhere appear improbable to me. I have not seen this except in the Wood Mountain area.

Helianthus tuberosus var subcanescens. Jerusalem Artichoke. Estevan area only. Grows among brush along with Western Snowberry. In no present danger.

Heliopsis helianthoides var scabra. Sunflower Heliopsis. Said to grow around edges of bluffs in north-east part of Park Belt, an area much subject to invasion of lands not cultivated by brome grass and sow thistle. I have never seen it, much less collected it, so I presume it's much reduced.

Hymenoxys acaulis. Stemless Rubberweed. There are scattered reports or collections from various parts of S.W. Saskatchewan, but I know this only from one coulee south of Mortlach. Breitung gives it a Cypress Hills range, but I've never seen it there. Probably this always was sporadic at least, but now is much reduced.

Senecio integerrimus. Entire-leaved Ragwort. Same comments as Shining Arnica.

\section{COMPOSITAE: LIGULIFLORAE - CHICORY SUB FAMILY}

Crepis occidentalis - Crepis intermedia complex. Western Hawksbeard. Cypress Hills: outlying station at Matador.

Hieracium albiflorum Hook. Whiteflowered Hawksbeard. Cypress Hills.

Lactuca biennis. Tall White Lettuce. OK in southern half of Boreal Forest area; much reduced in Park Belt a little to the south, mostly due to sowthistle spread.

Lactuca ludoviciana, Western Lettuce, has been reported by Breitung and Boivin from Regina and Gainsborough. ${ }^{2} 1$ We have no specimens in the Fraser Herbarium, and I have never observed it.

Lygodesmia rostrata. Annual Skeleton Weed. An annual of bare sands in S.W. Saskatchewan, subject to extermination if blowouts are permitted to revegetate. It is in the same position as Small Lupine.

Microseris cuspidata. Cuspidate Small Lettuce. A few records from coulee slopes and grassy hillsides in south-central Saskatchewan - Lebret, Lumsden, Mortlach, Big Muddy Valley. Very early flowering and whole plant quickly shrivelling - hence the fewness of the collections.

Prenanthes alba. White Lettuce. Rare in rich aspen woods, east half of Park Belt. Not resistant to grazing, trampling or invasion by bromegrass or sowthistle. Probably reduced.

Prenanthes racemosa. Glaucous White Lettuce. Somewhat drier aspen woods in entire Park Belt as far south as Saskatoon. Invasion of aspen bluffs by bromegrass has been particularly damaging to this species. Stephanomeria runcinata. Rush Pink. Con- 
fined to outcrops of the non-bentonitic powder-shale members of the Bearpaw formation in S.W. Saskatchewan. I have seen or collected it at Beechy, the Morgan Creek badlands, Horse Creek, and the Frenchman River canyon 35 miles southeast of Val Marie.

'BOIVIN, B. 1967. Flora of the Prairie Provinces, a handbook to the flora of the provinces of Manitoba, Saskatchewan, Alberta, Parts I, II, III. Pro- vancheria 2, Memoires de l'Herbier Louis Marie, Faculte d'Agriculture, Universite Laval, and Department of Agriculture, Ottawa.

${ }^{2}$ BREITUNG, A. J. 1957. Annotated catalogue of the vascular flora of Saskatchewan. American Midland Naturalist 58: $1-72$.

${ }^{3}$ HITCHCOCK, C. L. and A. CRONQUIST. 1964. Vascular plants of the Pacific Northwest, Part II. Univ. of Washington Press. 508-510.

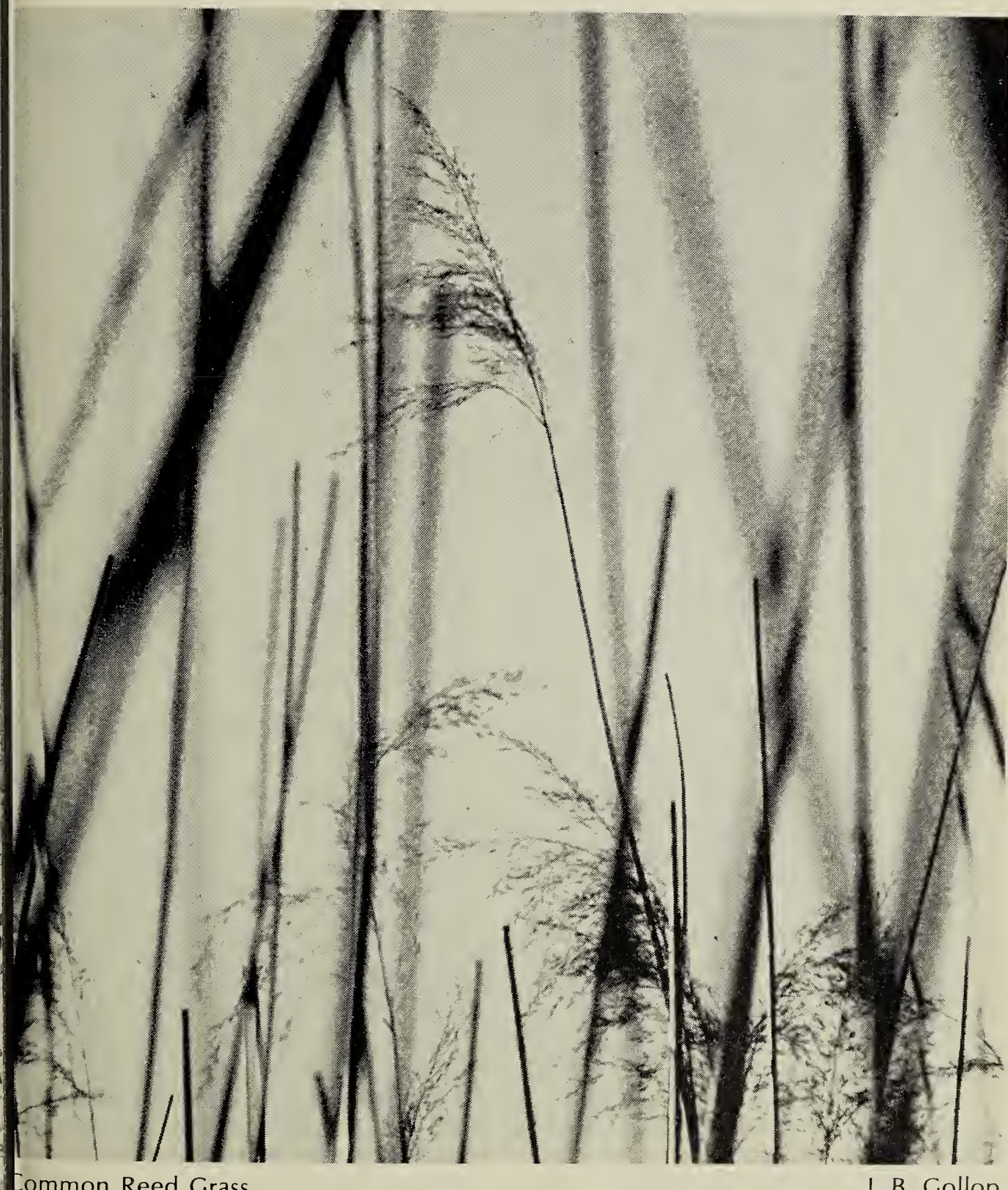

Common Reed Grass

J. B. Gollop 